\title{
Effectiveness of Planned Teaching Program (PTP) on Breast Cancer among Working Women at Selected Colleges in Haridwar, Uttrakhand
}

\author{
Ruchi, RN RM \\ Assistant Professor, College of Nursing, SSBCON, Ranipur Jhal, Jwalapur Haridwar UK 242403 \\ Statement of the Problem \\ "A study to assess the effectiveness of planned teaching program (PTP) on breast cancer among working women at \\ selected colleges in Haridwar, Uttrakhand

\begin{abstract}
Background: The magnitude of cancer is increasing day by day. It is one of the most dreaded diseases. At present is cancer is the second largest killer disease (nest to the hard disease). With the increasing control of communicable a nutritional disease, cancer now has become a major cause of morbidity and mortality and a heavy burden on health care system throughout the world. Cancer is to a large extent avoidable. Many cancers can be prevented others can be detected early in their developments, treated and cured. Even in case of late stage cancers, the pain can be reduced and the progression of the cancer slowed. Objectives: To assess the knowledge of working women regarding breast cancer before and after the administration of planned teaching program. To find out the effectiveness of planned teaching program regarding breast cancer. To determine the association between pre test knowledge score of working women regarding breast cancer and with their selected demographic variables.
\end{abstract}

Keywords: Working women, Breast cancer, Planned teaching program, Knowledge, Effective

\section{Hypotheses of the Study}

H1- There will be significant difference between the mean pre test knowledge scores and mean post-test knowledge scores of working women on breast cancer as evident from structured knowledge questionnaire at 0.05 level of significance.

$\mathrm{H} 2$ - There will be significant association between the mean pre test knowledge scores and with their demographic variables of working women at 0.05 level of significance as measured by structured knowledge questionnaire .

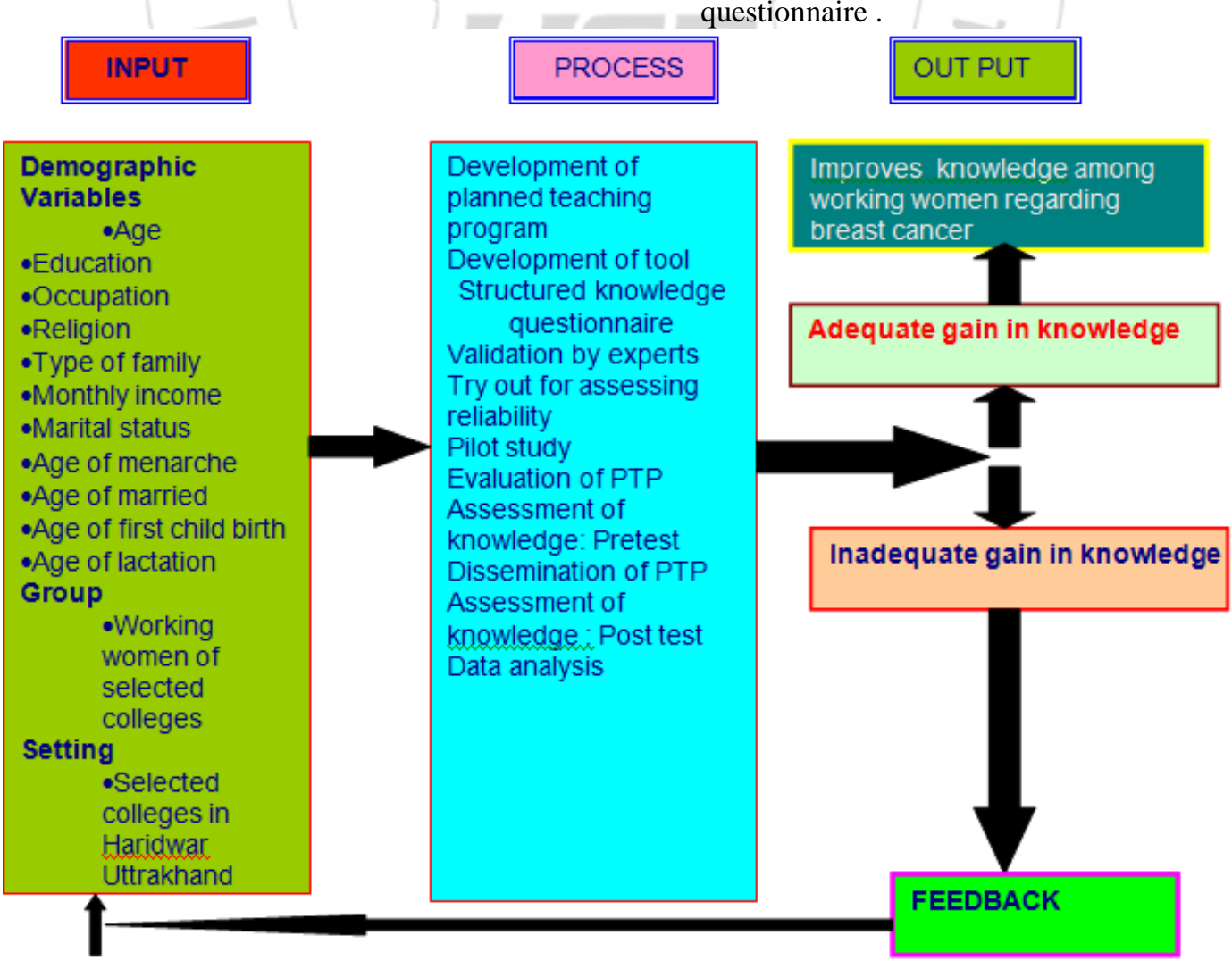

Methodology

Figure 1: Conceptual Framework 


\section{International Journal of Science and Research (IJSR) \\ ISSN (Online): 2319-7064}

Index Copernicus Value (2013): 6.14 | Impact Factor (2015): 6.391

The research design selected for the present study represents as:-

\section{OK1 - X - OK2}

\section{Methodology}

OK1 - is the knowledge test on breast cancer for working women before administration of planned teaching program.

$\mathbf{X}$ - is treatment i.e. planned teaching program on breast cancer

OK2 - is the knowledge test on breast cancer for working women after administration of planned teaching program

Table 1

\begin{tabular}{|c|c|c|c|}
\hline Group & \multicolumn{2}{|c|}{ Day $1^{\text {st }}$} & Day $8^{\text {th }}$ \\
\hline $\begin{array}{c}\text { Working women at } \\
\text { selected colleges in } \\
\begin{array}{c}\text { Haridwar, } \\
\text { Uttrakhand }\end{array}\end{array}$ & $\begin{array}{c}\text { Knowledge } \\
\text { test (OK1) }\end{array}$ & $\begin{array}{c}\text { Administration } \\
\text { of PTP }\end{array}$ & $\begin{array}{c}\text { Knowledge } \\
\text { test (ok2) }\end{array}$ \\
\hline
\end{tabular}

The population of the present study comprised of working women in selected women's college of Haridwar, Uttarakhand. Sample is of working women in selected women's college of Haridwar, Uttarakhand. Sampling technique: purposive sampling technique. Sample size: 60 working women

Table 2: Level of Knowledge

\begin{tabular}{|c|c|}
\hline Level of Knowledge & Range \\
\hline Poor & $0-14$ \\
\hline Average & $15-25$ \\
\hline Good & $26-35$ \\
\hline
\end{tabular}

\section{Final Data Collection Procedure}

Formal written permission was obtained from principal of SMJN degree college and HOD of Home Science Department, MV(PG) Kankhal, Haridwar to conduct the final study.Data was collected from $1^{\text {st }}$ June to $20^{\text {th }}$ Julne2011. Purpose of the study was explained to the subjects in order to get frank and free responses. Rapport was established with each of the subject.Confidentiality of their response was assured. A total of 60 samples were selected from selected colleges of Haridwar, Uttrakhand .

\section{Analysis}

distribution of working women using according to their age, education and occupation, religion, type of family, income, marital status, age at marriage, age at first child birth, age at lactation.

Majority of working women $29(48.33 \%)$ were in the age group of 31-40years, $21(35 \%)$ were in the age group of 21 30years, $9(16.7 \%)$ were in the age group of $40-51$ years and no subject was above 51 years.

Majority of the subjects $27(45 \%)$ were postgraduate, 18 $(30 \%)$ were graduate, $10(16.67 \%)$ had secondary education, $5(8.33 \%)$ had any other education. Majority of the subjects $37(61.5 \%)$ were teaching staff, $11(18.3 \%)$ were office staff,
$7(11.7 \%)$ were other staff and $5(8.3 \%)$ were belong to professional group. Majority of the women 29 (48.3\%) were Hindu, $16(26.7 \%)$ were Muslim, 12(20\%) were Sikh, and only $3(5 \%)$ were Christian. Majority of the women 30 (50\%) belongs to nuclear family, $18(30 \%)$ belongs to extended family and $12(20 \%)$ were from joint family. Majority of working women $28(46.67 \%)$ were in the monthly income group between Rs 15001- 20,000, $13(21.67 \%)$ were in the monthly income group above Rs $21,001,12(20 \%)$ were in the monthly income group between Rs $10,001-15,000$, and only 7 (11.67\%) were in the monthly income group between Rs 5,001-10,000.

Majority of the working women $44(73.33 \%)$ were married, $12(20 \%)$ were unmarried, $3(5 \%)$ were separated and only $1(1.7 \%)$ was widow.Majority of the subject $37(61.5 \%)$ had menarche below 14 years , 20(33.33\%) had menarche below 12 years were , $2(3.3 \%)$ had menarche above 14 years and only $1(1.7 \%)$ had menarche below 10 years .Majority of the subject $32(66.7 \%)$ had married at the age of between 18-23 years , 10(20.83\%) had married at the age of between 24-29 years , $6(12.5 \%)$ had married below 18 years and no one had married above 30 years .Majority of the subject $29(60.4 \%)$ had first child at the age of between $21-25$ years , $10(20.83 \%)$ had first child at the age of between 16-20 years , $9(18.8 \%$ ) had first child at the age of between 26-30 years and no one had first child above 30 years. Majority of the subject 29(60.4\%) started lactation at the age of between $21-25$ years , $10(20.83 \%)$ started lactation at the age of between $16-20$ years, $9(18.8 \%)$ started lactation at the age of between 26-30 years and no one started lactation above 30 year

Finding related to knowledge scores of working women regarding breast cancer This section describes the analysis and interpretation of data collected to evaluate effectiveness of planned teaching program on breast cancer for working women in term of gain in knowledge scores of working women. The pre-test and post-test knowledge scores obtained through structured knowledge questionnaire were described and analyzed using descriptive and inferential statistics.

Table 3: Frequency and percentage distribution of working women according to their level of knowledge regarding breast cancer, $\mathrm{N}=60$

\begin{tabular}{|c|c|c|c|c|c|}
\hline & & \multicolumn{2}{|c|}{ Pre-test } & \multicolumn{2}{c|}{ Post-test } \\
\hline Level of knowledge & Range & F & \% & F & \% \\
\hline Poor & $0-14$ & 24 & 40 & - & - \\
\hline Average & $15-25$ & 36 & 60 & 30 & 50 \\
\hline Good & $26-35$ & - & - & 30 & 50 \\
\hline
\end{tabular}

Data presented in table-3 indicate that majority of subject $36(40 \%)$ had average pre-test knowledge score,24(40\%) had poor pre-test knowledge score,30(50\%) had average posttest knowledge score and $30(50 \%)$ had good post-test knowledge score. 


\section{International Journal of Science and Research (IJSR) \\ ISSN (Online): 2319-7064}

Index Copernicus Value (2013): 6.14 | Impact Factor (2015): 6.391

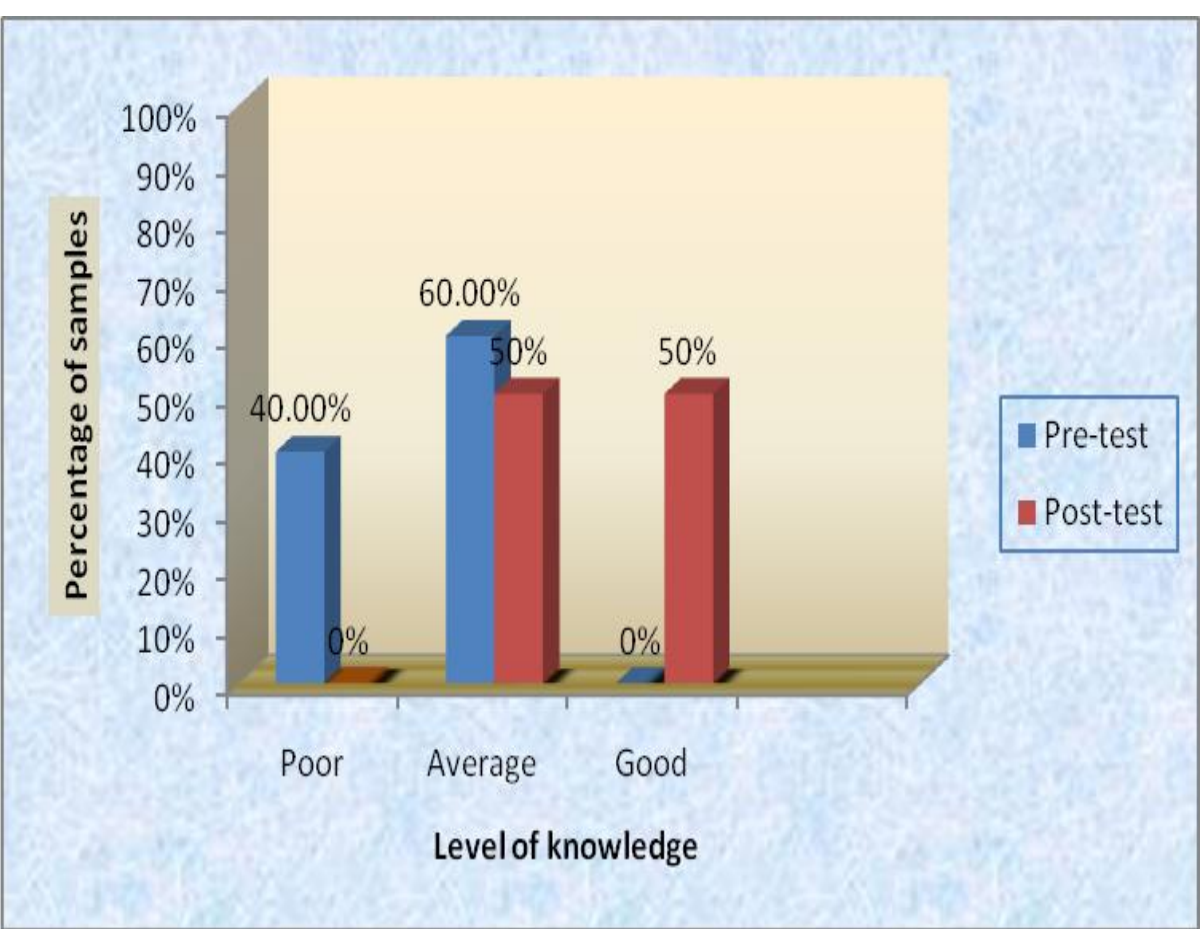

Figure 2: Bar diagram showing percentage distribution of the sample according to the pre-test and post-test level of knowledge

Table 4: Range, mean, median, standard deviation and mean percentage of pre-test and post-test knowledge of working women, $\mathrm{N}=60$

\begin{tabular}{|c|c|c|c|c|c|}
\hline & $\begin{array}{c}\text { Obtained } \\
\text { range }\end{array}$ & Mean & Median & $\begin{array}{c}\text { Standard } \\
\text { deviation }\end{array}$ & Mean \% \\
\hline Pre-test & $10-24$ & 15.48 & 15 & 2.91 & 44.22 \\
\hline Post-test & $15-33$ & 25.27 & 25.5 & 3.86 & 72.2 \\
\hline
\end{tabular}

Data presented in Table 4 shows that post-test knowledge scores ranged between 15-33 and pre-test knowledge score ranged from 10-24. Mean post-test knowledge score (25.27)of working women with median ( 25.5) was higher than mean pre-test knowledge score (15.48) with median( 15). As mean post -test knowledge score was higher than the mean pre-test score the planned teaching program was found to be effective in improving knowledge of working women at selected colleges in Haridwar.

Table 3 further shows that the standard deviation of post-test knowledge score(3.86) of working women with mean percentage(72.2) was higher than the standard deviation of pre-test knowledge score(2.91) of working women with mean percentage $(44.22)$

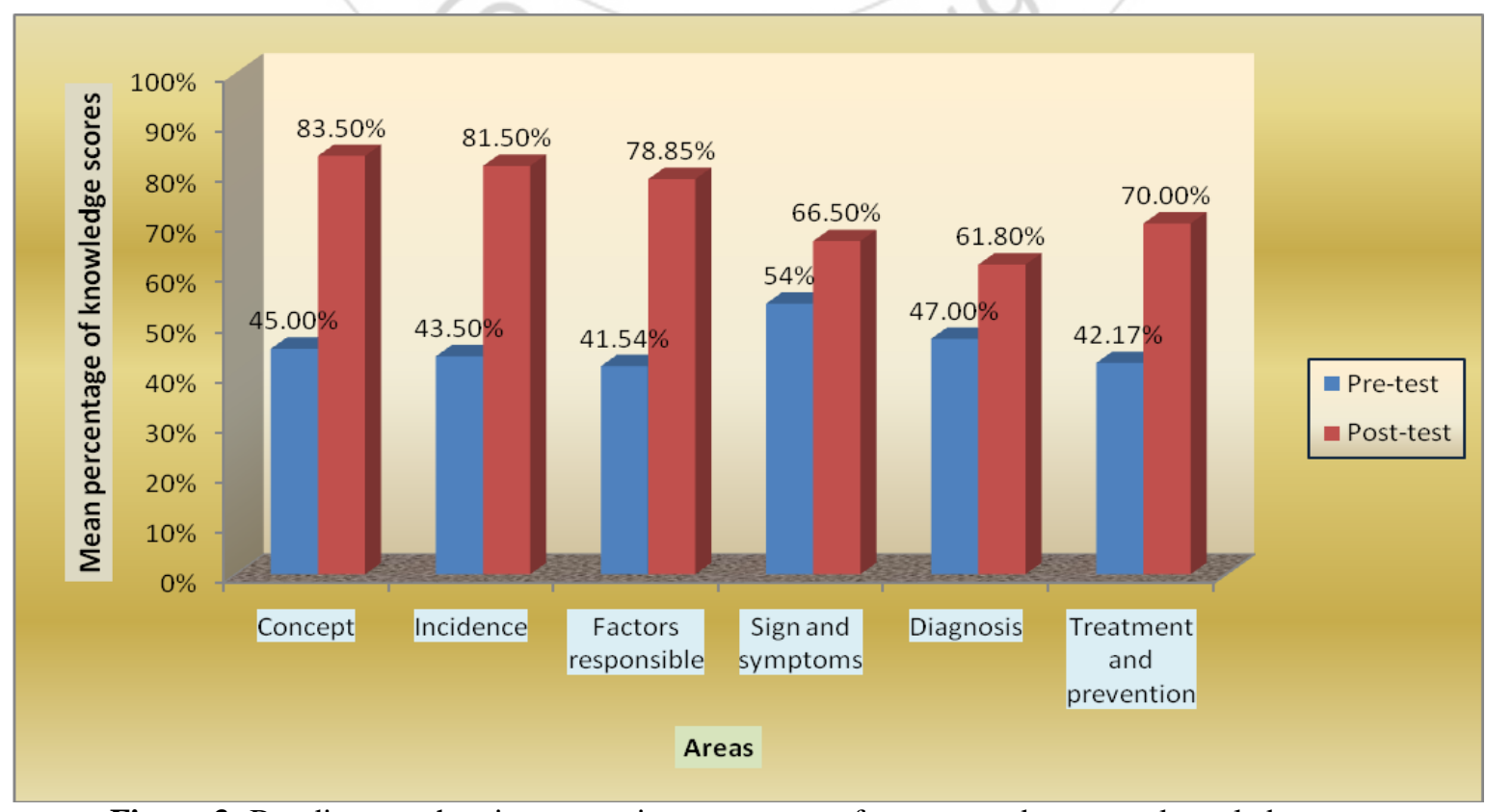

Figure 3: Bar diagram showing area-wise percentage of pre-test and post-test knowledge score 


\section{International Journal of Science and Research (IJSR) \\ ISSN (Online): 2319-7064 \\ Index Copernicus Value (2013): 6.14 | Impact Factor (2015): 6.391}

Data presented in Figure- 16 Bar diagram shows that posttest mean percentage of knowledge score $83.50 \%$ on concept of breast cancer was higher than pre-test mean percentage of knowledge score $45 \%$.The planned teaching program was found to be effective in improving knowledge of working women at selected colleges in Haridwar.

Finding also revealed that post-test mean percentage of knowledge score $81.50 \%$ on incidence of breast cancer was higher than pre-test mean percentage of knowledge score $43.50 \%$. The planned teaching program was found to be effective in improving knowledge of working women at selected colleges in Haridwar.

Finding also revealed that post-test mean percentage of knowledge score $78.85 \%$ on risk factor of breast cancer was higher than pre-test mean percentage of knowledge score $41.54 \%$. The planned teaching program was found to be effective in improving knowledge of working women at selected colleges in Haridwar.

Finding also revealed that post-test mean percentage of knowledge score $66.50 \%$ on sign symptoms of breast cancer was higher than pre-test mean percentage of knowledge score $54 \%$.The planned teaching program was found to be effective in improving knowledge of working women at selected colleges in Haridwar

Finding also revealed that post-test mean percentage of knowledge score $61.80 \%$ on diagnosis of breast cancer was higher than pre-test mean percentage of knowledge score $47 \%$.The planned teaching program was found to be effective in improving knowledge of working women at selected colleges in Haridwar

Finding also revealed that post-test mean percentage of knowledge score $70 \%$ on treatment and prevention of breast cancer was higher than pre-test mean percentage of knowledge score $42.17 \%$.The planned teaching program was found to be effective in improving knowledge of working women at selected colleges in Haridwar

Table 5: Mean, Mean difference and ' $t$ ' value on pre-test and post-test knowledge score, $\mathrm{N}=60$

\begin{tabular}{|c|c|c|c|c|}
\hline Parameter & Mean & $\begin{array}{c}\text { Standard } \\
\text { deviation }\end{array}$ & $\begin{array}{c}\text { Mean } \\
\text { difference }\end{array}$ & ' $t$ ' value \\
\hline Pre-test & 15.48 & 2.91 & \multirow{2}{*}{9.79} & $29.098 *$ \\
\hline Post-test & 25.27 & 3.86 & & \\
\hline
\end{tabular}

$\mathrm{T}_{59}=1.671, \mathrm{p}<0.05$

*Significant

* Significant at 0.05 level of significance

Data presented in Table -5 shows that mean post-test knowledge score (25.27) was higher than mean pre-test knowledge score(15.48) with a mean difference of (9.79). Obtained mean difference was found to be statistically significance as evident from ' $t$ 'value of (29.098) at 0.05 level of significance. This indicated that the planned teaching program on breast cancer was effective in increasing the knowledge of working women regarding breast cancer at selected colleges of Haridwar Uttrakhand.
Table 6: Mean, mean difference, SD and 't' value of pre-test and post-test knowledge scores, $\mathrm{N}=60$

\begin{tabular}{|c|c|c|c|c|c|c|}
\hline \multirow{2}{*}{ Area } & \multicolumn{2}{|c|}{ Pre-test } & \multicolumn{2}{|c|}{ Post-test } & Mean & 't' \\
\cline { 2 - 5 } & Mean & $\begin{array}{c}\text { Standard } \\
\text { deviation }\end{array}$ & Mean & $\begin{array}{c}\text { Standard } \\
\text { deviation }\end{array}$ & $\begin{array}{c}\text { difference } \\
\text { value }\end{array}$ \\
\hline Concept & 0.90 & 0.78 & 1.67 & 0.51 & 0.77 & $7.147^{*}$ \\
\hline Incidence & 0.87 & 0.6 & 1.63 & 0.52 & 0.76 & $7.74^{*}$ \\
\hline $\begin{array}{c}\text { Factors } \\
\text { responsible }\end{array}$ & 5.40 & 1.92 & 10.25 & 2.04 & 4.85 & $16.51^{*}$ \\
\hline $\begin{array}{c}\text { Sign and } \\
\text { symptoms }\end{array}$ & 1.08 & 0.62 & 1.33 & 0.68 & 0.25 & $2.261^{*}$ \\
\hline Diagnosis & 4.70 & 1.56 & 6.18 & 1.77 & 1.48 & $5.121^{*}$ \\
\hline $\begin{array}{c}\text { Treatment } \\
\text { and } \\
\text { prevention }\end{array}$ & 2.53 & 1.32 & 4.2 & 1.36 & 1.67 & $7.856^{*}$ \\
\hline Combined & 2.58 & 1.04 & 3.58 & 1.14 & 1.63 & 4.135 \\
\hline
\end{tabular}

$\mathrm{T}_{59}=1.671, \mathrm{p}<0.05$

* = Significant

* Significant at 0.05 level of significance

Data presented in Table -6 shows that the obtained ' $t$ ' value in all six content area of knowledge was statistically significance at 0.05 level It indicate that the planned teaching program on breast cancer was effective in increasing the knowledge in all six learning area of working women at selected colleges of Haridwar Uttrakhand.

Table 7: Chi-square test showing association of pre-test knowledge score with selected demographic variables, $\mathrm{N}=$ 60

\begin{tabular}{|c|c|c|c|c|c|c|}
\hline \multirow{2}{*}{$\begin{array}{c}\text { S. } \\
\text { No }\end{array}$} & $\begin{array}{c}\text { Demographic } \\
\text { variables }\end{array}$ & \multicolumn{2}{|c|}{ Table value } & $\begin{array}{c}\text { Level of } \\
\text { significance }\end{array}$ & df & Inference \\
\hline 1 & Age in years & 2.53 & 5.991 & $\mathrm{p}>0.05$ & 2 & $\mathrm{NS}$ \\
\hline 2 & $\begin{array}{c}\text { Education } \\
\text { status }\end{array}$ & 14.16 & 7.815 & $\mathrm{P}<0.05$ & 3 & $\mathrm{~S} *$ \\
\hline 3 & Occupation & 9.21 & 7.815 & $\mathrm{P}<0.05$ & 3 & $\mathrm{~S} *$ \\
\hline 4 & Religion & 0.297 & 7.815 & $\mathrm{p}>0.05$ & 3 & $\mathrm{NS}$ \\
\hline 5 & $\begin{array}{c}\text { Type of } \\
\text { family }\end{array}$ & 1.17 & 5.991 & $\mathrm{p}>0.05$ & 2 & $\mathrm{NS}$ \\
\hline 6 & $\begin{array}{c}\text { Family } \\
\text { income }\end{array}$ & 13.85 & 7.815 & $\mathrm{P}<0.05$ & 3 & $\mathrm{~S} *$ \\
\hline 7 & $\begin{array}{c}\text { Marital } \\
\text { status }\end{array}$ & 3.37 & 7.815 & $\mathrm{p}>0.05$ & 3 & $\mathrm{NS}$ \\
\hline 8 & $\begin{array}{c}\text { Age at } \\
\text { menarche }\end{array}$ & 5.44 & 7.815 & $\mathrm{p}>0.05$ & 3 & $\mathrm{NS}$ \\
\hline 9 & $\begin{array}{c}\text { Age at } \\
\text { marriage }\end{array}$ & 3.29 & 7.815 & $\mathrm{p}>0.05$ & 3 & $\mathrm{NS}$ \\
\hline 10 & $\begin{array}{c}\text { Age of first } \\
\text { child birth }\end{array}$ & 1.46 & 7.815 & $\mathrm{p}>0.05$ & 3 & $\mathrm{NS}$ \\
\hline 11 & $\begin{array}{c}\text { Age of } \\
\text { lactation }\end{array}$ & 1.46 & 7.815 & $\mathrm{p}>0.05$ & 3 & $\mathrm{NS}$ \\
\hline
\end{tabular}

\section{Conclusion}

Data presented in table-3 indicate that majority of subject $36(40 \%)$ had average pre-test knowledge score,24(40\%) had poor pre-test knowledge score,30(50\%) had average posttest knowledge score and 30(50\%) had good post-test knowledge score. the planned teaching program on breast cancer was effective in increasing the knowledge of working women regarding breast cancer at selected colleges of Haridwar Uttrakhand. Data presented in Table -6 shows that 
the obtained ' $t$ ' value in all six content area of knowledge was statistically significance at 0.05 level It indicate that the planned teaching program on breast cancer was effective in increasing the knowledge in all six learning area of working women at selected colleges of Haridwar Uttrakhand.

\section{Declaration}

A declaration stating that "A study to assess the effectiveness of planned teaching program (PTP) on breast cancer among working women at selected colleges in Haridwar, Uttrakhand is my original research work that has not been published and has not been sent for publication anywhere else."

\section{Authors' Undertaking}

Acknowledgement: not required,

Funding: none from any source

Informed consent: required

Conflict of interest: none to declare,

Ethical clearance: not required

Authors' contribution: Mrs. Ruchi, Assistant professor, College of Nursing, SSBCON, Ranipur Jhal, Jwalapur

Haridwar

\section{References}

[1] Abdellah , F.G. and E.Levine. Better Patients Care Through Nursing Research. New York: Macmillan company, 1981.

[2] Aggarwal, S.P et al. Fifty years of Cancer Control in India. National Cancer Control Program, DGHS.2002.

[3] Beck , C.K; et al. Mental Health Psychiatric Nursing- A Holistic Life Cycle Approach. $2^{\text {nd }}$ edition; St. Louis: C.V.Mosby Co,1985,934-935.

[4] Best, John W. Research in Education. New Delhi; Prentice Hall of India. Pvt Ltd; 1982

[5] American Cancer Society (2009). What are the risk factors for breast cancer? Detailed guide: Breast cancer. Cancer Reference Information. Available online: http://www.cancer.org/docroot/CRI/content/CRI_2_4_2 X_What_are_the_risk_factors_for_breast_cancer_5.asp.

[6] American Cancer Society (2007). Breast Cancer Facts and Figures 2007. Atlanta: American Cancer Society. Available online: http://www.cancer.org/docroot/STT/stt_0.asp 